\title{
MANAJEMEN KURIKULUM PENDIDIKAN AL-ISLAM DAN KEMUHAMMADIYAHAN DI SEKOLAH TINGGI KEGURUAN DAN ILMU PENDIDIKAN MUHAMMADIYAH PALOPO
}

\author{
Syamsu S. \\ Institut Agama Islam Negeri Palopo \\ Jl. Agatis Balandai Kota Palopo, SulSel, Indonesia \\ E-mail: syam1954783@gmail.com
}

\begin{abstract}
The subjects of Al-Islam and Kemuhammadiyahan (AIK) are the terms of Islamic Religious Education courses applied to universities of Muhammadiyah which is very significantin forming students as professional, intellectual, and personal religious learning learner according to the guidance of Islam that upholds the value of humanity, and able to compete in the era of globalization, therefore the implementation process of AIK curriculum subjects must be well managed, structured, and systematic. This research is qualitative descriptive, conducted in STKIP Muhammadiyah Palopo, aimed to describe the implementation of curriculum management of the subjects of al-Islam and Kemuhammadiayahan in STKIP Muhammadiyah Palopo. Data collection techniques used interview, observation, and documentation. Data analysis used data reduction techniques, data display, and conclusions. The results showed that AIK curriculum management functions in STKIP Muhammadiyah Palopo were well implemented, supported by muhammadiyah cadres and other stakeholders.
\end{abstract}

Keywords: Management, Curriculum, Al-Islam and Kemuhammadiyahan

\begin{abstract}
Abstrak
Mata kuliah Al-Islam dan Kemuhammadiyahan (AIK) adalah istilah mata kuliah Pendidikan Agama Islam yang diterapkan pada perguruan tinggi kemuhammadiyahan sangat signifikan dalam membentuk mahasiswa sebagai manusia pembelajar yang profesional, intelektual, dan personal religius sesuai tuntunan Islam yang menjunjung tinggi nilai kemanusiaan, dan mampu berkompetisi di era globalisasi, karena itu proses implementasi kurikulum mata kuliah AIK harus diawali dengan manajemen yang baik, terstruktur, dan sistematis. Penelitian ini bersifat deskriptif kualitatif, dilaksanakan di STKIP Muhammadiyah Palopo, bertujuan untuk mendeskripsikan implementasi manajemen kurikulum mata kuliah al-Islam dan Kemuhammadiayahan di STKIP Palopo. Teknik pengumpulan data digunakan wawancara, observasi, dan dokumentasi. Analisis data digunakan teknik reduksi data, penyajian data, dan penarikan kesimpulan. Hasil penelitian menunjukkan bahwa fungsi-fungsi manajemen kurikulum mata kuliah Al-Islam dan Kemuhammadiyahan (AIK) di STKIP Muhammadiyah Palopo dilaksanakan dengan baik, didukung oleh kader perserikatan muhammadiyah dan stakeholder lainnya.
\end{abstract}

Kata Kunci,: Manajemen, Kurikulum, Al-Islam dan Kemuhammadiyahan 


\section{2 | Syamsu $S$.}

\section{PENDAHULUAN}

Manajemen merupakan proses pemberdayaan berbagai sumber daya dalam rangka mencapai tujuan yang telah ditetapkan. Kegiatan yang merupakan ruang lingkup manajemen mencakup perencanaan, pengorganisasian, pelaksanaan, dan pengawasan. Manajemen yang mencakup ruang lingkupnya seperti ini dalam implementasinya memanfaatkan sumber daya manusia dan sumber daya lainnya untuk mencapai tujuan yang telah ditetapkan. ${ }^{1}$ Dalam manajemen ada proses, memberdayakan orang lain atau sumber daya lainnya, dan ada tujuan yang telah akan dicapai.

Pendidikan agama pada perguruan tinggi diatur dalam Keputusan Dirjen Dikti No. 43/DIKTI/Kep/2006, mata kuliah agama dimasukkan dalam Mata Kuliah Pengembangan Kepribadian (MPK). Pendidikan Islam dalam kurikulum perguruan tinggi mempunyai posisi strategis, karena bertujuan membentuk lulusan yang profesional pada bidangnya, memiliki karakter, bermoral, dan berakhlak yang sesuai tuntunan Islam yang menjunjung tinggi nilai kemanusiaan. Karena itu, Roqib berpendapat bahwa pendidikan Islam harus diajarkan dalam bentuk integrasi transenden sehingga tidak terjadi bias antara ilmu umum dengan perspektif Islam. ${ }^{2}$

Studi awal yang dilakukan di STKIP (Sekolah Tinggi Keguruan dan Ilmu Pendidikan) Muhammadiyah Palopo diketahui bahwa mata kuliah Al-Islam dan Kemuhammadiyahan (AIK) adalah mata kuliah pendidikan Islam merupakan diskresi Pimpinan Pusat Muhammadiyah yang tertuang dalam SK. No. 027/SK-MPT/III.B/1996 tentang Kurikulum Pendidikan Al-Islam dan Kemuhammadiyahan. Diskresi ini juga dipertegas oleh Rektor Universitas Muhammadiyah Malang. ${ }^{3}$

STKIP Muhammadiyah Palopo mendistribusikan mata kuliah AIK mulai dari semester 1 sampai semester 8, sehingga proses perkuliahannya harus dirancang dengan baik dan sistematis. Bobot sks persemester yakni 2 sks, dengan demikian bobot sks dalam kurun waktu 8 semester berjumlah 16 sks. STKIP ini masih tergolong baru, program perkuliahan baru berada pada semester 4, oleh karena itu bobot sks mata kuliah Al-Islam dan Kemuhammadiyahan (AIK) yang sudah terlaksana berjumlah 8 sks. $^{4}$

${ }^{1}$ R. Eko Indrajit dan R. Djokopranoto, Manajemen Perguruan Tinggi Modern, (Yogyakarta: ANDI, 2006), h. 27.

2Moh. Roqib, Ilmu Pendidikan Islam, (Yogyakarta: LkiS, 2009), h. 78.

${ }^{3}$ Rektor Universitas Muhammadiyah Malang. Makalah disampaikan pada Lokakarya Integrasi dan Implementasi Perkuliahan AIK di PTM pada tanggal 18 Juni 2017. http://www.umm.ac.id/id/berita/aik-ciri-khas-perguruan-tinggi-muham madiyah.html

4Duriani, Dosen AIK, Wawancara, 5 Oktober 2017. 
Pengembangan kurikulum sebagaimana yang dilakukan pada STKIP Muhammadiyah Palopo bisa dilakukan, hal ini didukung oleh hasil riset sebelumnya oleh Syamsul Arifin menyatakan, pengembangan Al-Islam dan Kemuhammadiyahan (AIK) sebagai mata kuliah, penting dilakukan dengan pertimbangan Al-Islam dan Kemuhammadiyahan (AIK) disetarakan dengan mata kuliah Pendidikan Agama Islam. ${ }^{5}$ Che Noraini Hashim melakukan penelitian tentang pengembangan kurikulum pendidikan Agama Islam di Indonesia dan Malaysia menyatakan bahwa perlu reformasi pengembangan kurikulum pendidikan agama terkait dengan tantangan yang dihadapi kedua negara tersebut. ${ }^{6}$ Hasil penelitian tersebut relevan dengan diskresi pengembangan Al-Islam dan Kemuhammadiyahan (AIK) sebagai mata kuliah pendidikan agama di STKIP Muhammadiyah Palopo.

Eksistensi mata kuliah Al-Islam dan Kemuhammadiyahan (AIK) sangat signifikan dalam membentuk mahasiswa yang profesional-religius, intelektual-religius, dan personal-religius yang mampu berkompetisi di era globalisasi. Harapan tersebut didasari pada tujuan umum mata kuliah AIK yang akan dicapai, yakni terbentuknya manusia pembelajar yang bertakwa, berakhlak mulia, berkemajuan dan unggul dalam IPTEKS sebagai perwujudan tajdid dakwah amar ma'rufnahi munkar. ${ }^{7}$

Signifikansi penelitian ini berpijak pada realita, bahwa STKIP ini tergolong muda. Jauh sebelumnya sudah ada IAIN Palopo dan STKIP Cokroaminoto Palopo yang memiliki fakultas pendidikan dan keguruan. Namun demikian, jumlah mahasiswanya berimbang bahkan berkompetisi dengan kedua perguruan tinggi sebelumnya.

Manajemen kurikulum dapat diartikan sebagai proses pengelolaan kurikulum. Manajemen kurikulum juga dapat diartikan sebagai sebuah proses atau sistem pengelolaan kurikulum secara kooperatif, komprehensif dan sistematik untuk mengacu ketercapaian tujuan kurikulum yang sudah dirumuskan. ${ }^{8}$ Karena itu, proses manajemen kurikulum tidak lepas dari kerjasama sosial antara dua orang atau lebih secara formal dengan bantuan

5Syamsul Arifin, "Rekonstruksi Al-Islam Kemuhammadiyahan (AIK) Perguruan Tinggi Muhammadiyah Sebagai Praksis Pendidikan Nilai, (EDUKASI: Jurnal Pendidikan Agama dan Keagamaan, Vol.13, Nomor 2, 2015), h. 201.

${ }^{6}$ Che Noraini Hashim dan Hasan Langgulung, Islamic Religous Curriculum In Muslim Countries:The Experiences of Indonesia and Malaysia, (Bulletin of Education and Research, Vol. 30, No. 1, 2008), h. 1.

${ }^{7}$ Pedoman Pendidikan AIK, Pendidikan Al-Islam dan Kemuhammadiyahan Perguruan Tinggi Muhammadiyah, (Yogyakarta: Majelis Pendidikan Tinggi PP Muhammadiyah, 2013), h. 24 .

8Sulistyorini, Manajemen Pendidikan Islam, (Yogyakarta: Teras, 2009), h. 40. 


\section{4 | Syamsu $S$.}

sumber daya yang mendukungnya. Pelaksanaannya dilakukan dengan metode kerja tertentu yang efektif dan efisien serta mengacu pada tujuan kurikulum yang sudah ditentukan sebelumnya.

Kajian tentang ruang lingkup manajemen kurikulum disajikan sebagai berikut.

\section{Perencanaan Kurikulum}

Perancangan kurikulum pendidikan tinggi dalam Panduan Penyusunan Kurikulum Pendidikan Tinggi Kemenristek Dikti disebutkan bahwa tahapan perancangan kurikulum merupakan kegiatan penyusunan konsep sampai dengan penyusunan mata kuliah dalam semester dari suatu program studi. ${ }^{9}$

Perencanaan kurikulum pendidikan tinggi meliputi: a) perumusan capaian perkuliahan lulusan (CPL), b) pembentukan mata kuliah, c) penyusunan mata kuliah dan struktur kurikulum, d) merumuskan capaian perkuliahan mata kuliah (CPMK), dan e) menyusun rencana perkuliahan semester (RPS). ${ }^{10}$

\section{Implementasi Kurikulum}

Implementasi atau pelaksanaan kurikulum menjadi aspek yang sangat penting dalam najaemen kurikulum. Felix menyatakan, bahwa implementasi kurikulum merupakan penerapan secara praktik rangkaian program dan silabus mata pelajaran yang telah disusun. ${ }^{11}$ Proses ini adalah proses dimana mahasiswa dibantu dalam mendapatkan pengetahuan atau pengalaman. Implementasi kurikulum menempatkan mahasiswa sebagai titik sentral dari proses pendidikan, dimana mahasiswa mendapatkan pengalaman, pengetahuan, kemampuan, ide, dan perilaku yang telah ditetapkan.

Penerapan kurikulum merupakan fase yang sangat penting dalam siklus kurikulum dimana pemilihan strategi digunakan untuk memilih kelengkapan seperti silabus/RPS, skema kerja, rencana perkuliahan, materi perkuliahan, buku teks dan bacaan lainnya serta lingkungan sekolah.

\section{Evaluasi Kurikulum}

Untuk mengetahui pencapaian kurikulum perlu dilakukan pengumpulan informasi untuk kemudian dilakukan evaluasi terhadap seluruh aspek

\footnotetext{
9Tim Penyusun, Panduan Penyusunan Kurikulum Pendidikan Tinggi, (Jakarta: Kemenristek Dikti, 2016), h. 7.

10Tim Penyusun, Panduan Penyusunan Kurikulum Pendidikan Tinggi, h. 30.

11Felix Mulengeki et.al, Curriculum Development and Evaluation, (Tanzania, University of Tanzania, 2013), h. 44.
} 
kurikulum untuk digunakan sebagai tolok ukur keberhasilan dan perbaikan mutu perkuliahan. Standar Nasional Pendidikan Tinggi pasal 39 ayat (2) dinyatakan bahwa perguruan tinggi dalam mengelola perkuliahan wajib melaksanakan pemantauan dan evaluasi terhadap kegiatan program studi dalam melaksanakan perkuliahan. ${ }^{12}$

Evaluasi kurikulum sangat penting dilaksanakan untuk memperoleh dan memberikan informasi yang berguna dalam membuat keputusan dan penilaian tentang kurikulum itu. Penilaian proses dan hasil belajar mahasiswa diperjelas dalam Standar Nasional Pendidikan Tinggi Pasal 19 ayat (1) dan (2) mencakup prinsip penilaian, teknik penilaian, instrumen penilaian, mekanisme dan prosedur penilaian, pelaksanaan penilaian, pelaporan penilaian, dan kelulusan mahasiswa. ${ }^{13}$

Dengan demikian, dari proses evaluasi tersebut akan diketahui sejauh mana keberhasilan pencapaian kurikulum. Setiap tahap perkuliahan dilakukan penilaian perkuliahan untuk menilai proses dan hasil perkuliahan. Berdasarkan pandangan tersebut, dipahami bahwa evaluasi kurikulum perlu dilakukan secara sistematis dan analisis sehingga dapat diperoleh data akurat dalam rangka pengambilan keputusan yang objektif.

\section{METODE}

Penelitian kualitatif deskriptif ini dilakukan di Sekolah Tinggi Keguruan dan Ilmu Pendidikan (STKIP) Muhammadiyah Kota Palopo Propinsi Sulawesi Selatan. Subjek penelitian yaitu tim dosen mata kuliah Al-Islam dan Kemuhammadiyahan (AIK), para pimpinan perguruan tinggi tersebut. Objek penelitian adalah manajemen kurikulum Al-Islam dan Kemuhammadiyahan. Teknik triangulasi digunakan untuk memverifikasi data hasil observasi, wawancara, dan dokumentasi. Teknik reduksi data, penyajian data, dan penarikan kesimpulan digunakan untuk mengolah dan menganalisis data. Hasil penelitian ini diharapkan dapat mendeskripsikan pelaksanaan manajemen kurikulum mata kuliah Al-Islam dan Kemuhammadiyahan (AIK) di STKIP Muhammadiyah Palopo.

\footnotetext{
12Republik Indonesia, Peraturan Menteri Riset, Teknologi, dan Pendidikan Tinggi nomor 44 tahun 2015 tentang Standar Nasional Pendidikan.

${ }^{13}$ Republik Indonesia, Peraturan Menteri Riset, Teknologi, dan Pendidikan Tinggi Nomor 44 tahun 2015 tentang Standar Nasional Pendidikan.
} 
66 | Syamsu $S$.

\section{PENERAPAN KURIKULUM AIK DI STKIP MUHAMMADIYAH PALOPO}

STKIP Muhammadiyah Palopo menerapkan kurikulum mata kuliah AlIslam dan Kemuhammadiyahan (AIK) dideskripsikan sebagai berikut.

\section{Perencanaan Kurikulum}

Mata kuliah Al-Islam dan Kemuhammadiyahan (AIK) pada STKIP Muhammadiyah Palopo memiliki dasar hukum yaitu Surat Keputusan Majelis Dikti PP Muhammadiyah No 027/SK-MPT/III.B/1996. Surat keputusan ini merujuk pada UU No. 12 Tahun 2012 pasal 35 ayat 2 yang men yatakan bahwa kurikulum dikembangkan oleh setiap perguruan tinggi. UU ini ditindaklanjuti dengan Peraturan Menteri Riset, Teknologi, dan Pendidikan Tinggi Nomor 44 Tahun 2015 tentang Standar Nasional Pendidikan Tinggi.

Perencanaan kurikulum Al-Islam dan Kemuhammadiyahan (AIK) dilakukan dengan membentuk tim dosen AIK terdiri atas dosen mata kuliah Al-Islam dan Kemuhammadiyahan (AIK) dalam lingkup Perguruan Tinggi Kemuhammadiyahan (PTM) di Kota Palopo yakni AKBID, STKIP, dan STIE. Tim ini bertugas untuk menentukan pendistribusian mata kuliah pada setiap jenjang semester beserta besaran bobot sksnya.

Mata kuliah AIK pada STKIP Muhammadiyah Palopo diajarkan pada 4 semester, yakni AIK I sampai AIK 4 diajarkan pada semester 1 sampai semester 4. Mata kuliah AIK I pada semester 1 diajarkan tentang Al-Islam dan Studi al-Qur'an, AIK II pada semester 2 diajarkan tentang Aqidah Islamiyah, AIK III pada semester 3 diajarkan tentang kemuhammadiyahan, dan AIK IV pada semester 4 diajarkan tentang Fiqih Ibadah.

Sistem kredit semester (SKS) mata kuliah merupakan pembobotan yang harus diselesaikan oleh mahasiswa. Penentuan bobot sks tetap memperhatikan bidang keilmuan dan jenjang pendidikan. Bobot sks mata kuliah Al-Islam dan Kemuhammadiyahan (AIK) berjumlah 8, masing-masing disebar pada 4 semester. Sebaran mata kuliah AIK pada jenjang semester dan bobot sks disajikan pada tabel berikut.

Tabel 1. Jenjang Semester, Mata Kuliah dan Ruang Lingkup, dan Jumlah SKS

\begin{tabular}{|c|l|c|}
\hline Semester & \multicolumn{1}{|c|}{ Mata Kuliah dan Ruang Lingkup } & $\begin{array}{c}\text { Jumlah } \\
\text { SKS }\end{array}$ \\
\hline 1 & AIK I, Al-Islam \& Studi al-Qur'an & 2 \\
\hline 2 & AIK II, Akidah Akhlak & 2 \\
\hline 3 & AIK III, Kemuhammadiyahan & 2 \\
\hline 4 & AIK IV, Fikih Ibadah & 2 \\
\hline \multicolumn{2}{|l}{ Jumlah } & 8 \\
\hline
\end{tabular}




\section{Pengorganisasian Kurikulum}

Pengorganisasian kurikulum dalam bentuk dokumen kurikulum yakni RPS dimana di dalamnya termuat tentang organisasi materi ajar, metode perkuliahan, media pembela-jaran, dan referensi. Pengorganisasian ini menjadi kewenangan dan tanggung jawab pembantu ketua bidang akademik.

Al-Islam dan Kemuhammadiyahan (AIK) merupakan mata kuliah tersendiri terpisah dengan mata kuliah lainnya sehingga bisa dikatakan bahwa kurikulum Al-Islam dan Kemuhammadiyahan (AIK) bersifat separated subject curriculum. Mata kuliah Al-Islam dan Kemuhammadiyahan (AIK) lebih mengedepankan ilmu-ilmu agama dan berorientasi pada padat isi sehingga mata kuliah ini cenderung menerapkan pendekatan teacher centered learning. Metode yang digunakan yakni metode ceramah, metode tanya jawab, metode demonstrasi, metode diskusi, metode resitasi, dan metode kerja kelompok. Media elektronik juga dimanfaatkan dalam proses perkulihan seperti laptop, LCD, dan handphone.

Sumber rujukan yang dipakai dalam kurikulum Al-Islam dan Kemuhammadiyahan (AIK) yaitu al-Qur'an, hadits, putusan majelis tarjih Muhammadiyah, buku pedoman pendidikan Al-Islam dan Kemuhammadiyahan (AIK), buku panduan terbitan PP Muhammadiyah dan sumber-sumber lain yang relevan.

\section{Implementasi Kurikulum}

Implementasi kurikulum merupakan proses tindak lanjut dokumen kurikulum dimana pelaksanaannya dalam bentuk proses perkuliahan, pada proses inilah merupakan tahapan yang menentukan tercapainya kurikulum mata kuliah Al-Islam dan Kemuhammadiyahan (AIK).

Penggunaan metode dan media perkuliahan disesuaikan dengan materi yang diajarkan seperti metode ceramah, metode demonstrasi, metode diskusi, metode pembagian tugas, metode kerja kelompok dan metode tanya jawab. Materi seperti membaca al-Qur'an digunakan metode demonstrasi dimana mahasiswa mendemonstrasikan secara langung membaca al-Qur'an satu persatu. Praktik thaharah atau sholat mahasiswa mendemonstrasikan tata cara thaharah atau tata cara sholat. Selain itu dosen juga memanfaatkan media perkuliahan seperti laptop dan LCD untuk menampilkan bahan ajar. Mahasiswa dianjurkan menggunakan handphone untuk mencari referensi yang digunakan, hal ini sangat bermanfaat sebagai sarana belajar dimana mahasiswa tidak perlu untuk membawa al-Qur'an dalam bentuk cetakan akan tetapi cukup dengan menggunakan aplikasi al-Qur'an pada handphone tersebut. Di akhir pertemuan, dosen menyimpulkan materi yang sudah 
68 | Syamsu $S$.

dipelajari, memberikan tugas terstruktur baik secara individu ataupun secara kelompok.

Fasilitas belajar merupakan hal yang mempengaruhi pemilihan dan penentuan metode mengajar. Tersedianya fasilitas belajar akan mempengaruhi pemilihan metode mengajar. Pembelajaran yang sifatnya praktikum atau latihan didukung oleh tersedianya fasilitas praktik. Dalam menentukan metode yang akan digunakan mempertimbangkan faktor ketersediaan fasilitas. Ada metode mengajar tertentu yang tidak dapat digunakan karena fasilitas belajar dalam kelas tidak tersedia.

4. Evaluasi Kurikulum

Evaluasi kurikulum Al-Islam dan Kemuhammadiyahan (AIK)dilakukan setiap semester untuk mengetahui pencapaian kurikulum. Hasil evaluasi dijadikan bahan rujukan untuk menentukan sikap dalam pengambilan keputusan. Evaluasi kurikulum tidak hanya mengevaluasi program perkuliahan, akan tetapi keseluruhan program mata kuliah AIK.

Proses evaluasi kurikulum Al-Islam dan Kemuhammadiyahan (AIK) dilakukan secara parsial dan holistik. Secara parsial kurikulum AIK dievaluasi pada tahap akhir proses perkuliahan dalam bentuk ujian tengah semester, praktikum, dan ujian akhir semester. Sedangkan evaluasi secara holistik dalam bentuk ujian komprehensif yang diujikan pada akhir penyelesaian studi.

Evaluasi kurikulum Al-Islam dan Kemuhammadiyahan (AIK) di STKIP Palopo dilakukan dengan dua teknik, yakni pertama, melalui teknik nontes dalam bentuk observasi yaitu proses mengetahui pencapaian kurikulum AlIslam dan Kemuhammadiyahan (AIK) dilakukan dengan mengamati pengamalan nilai-nilai keislam dan kemuhammadiyahan dalam praktik keseharian mahasiswa serta keaktifan dalam mengikuti proses perkuliahan. Kedua, melalui teknik tes, pada teknik ini dilakukan melalui tes diagnostik, tes formatif, tes sumatif, dan tes komprehensif.

Tes diagnostik, yaitu tes yang dilakukan untuk mengetahui kelemahan mahasiswa, selanjutnya dilakukan penanganan secara tepat. Tes diagnostik pada mata kuliah AIK dilakukan oleh dosen pada saat sebelum perkuliahan dimulai dimana informasi atas kelemahan mahasiwa pada mata kuliah AIK didapatkan dari hasil DAD yang dilaksanakan sebelum proses perkuliahan dimulai. Tes formatif, yaitu tes yang dilaksanakan untuk mengetahui pencapaian kompetensi mahasiswa setelah menyelesaikan satu atau beberapa sub materi ajar. Tes ini dilaksanakan dalam bentuk ulangan harian. Tes sumatif, yaitu tes yang dilaksanakan untuk mengetahui pencapaian kompetensi mahasiswa setelah menyelesaikan beberapa kali perkuliahan. Tes ini dilaksanakan dalam bentuk ujian tengah semester, dan ujian akhir semester. Tes komprehensif, yaitu tes yang dilaksanakan untuk mengetahui 
pencapaian kompetensi mahasiswa pada materi ajar mulai mata kuliah AIK secara keseluruhan. Tes jenis ini merupakan tes skala yang lebih besar. Artinya, materi ajar mulai semester I samapi semester VII harus diujikan, karena itu test ini dilaksanakan dalam bentuk ujian komprehensif. Pada tahapan jenis tes ini belum dilaksanakan di STKIP Muhammadiyah Palopo karena tingkatan mahasiswa sekarang masih berada pada semester 4 .

\section{PENUTUP}

Mata kuliah Al-Islam dan Kemuhammadiyahan (AIK) merupakan pengembangan mata kuliah pendidikan agama Islam yang diatur secara nasional dalam sistem pendidikan nasional bernuansa kemuhammadiyahan untuk menyesuiakan dengan kebijakan organisasi muhammadiyah secara nasional. Sebagai perguruan tinggi Islam, STKIP Muhammadiyah Palopo harus mengemban misi sebagai lembaga pengembangan keilmuan atau kajian-kajian keislaman, sekaligus sebagai lembaga keagamaan yang berusaha membangun sikap dan perilaku beragama yang loyal, memiliki komitmen terhadap Islam, serta penuh dedikasi terhadap agama yang diyakini kebenarannya atas dasar wawasan keilmuan keislaman yang dimiliki dengan tetap menjaga kerukunan hidup beragama yang dinamis.

Pengembangan kurikulum pendidikan memang menjadi suatu kebutuhan lembaga pendidikan dalam rangka menjawab tantangan kemajuan ilmu pengetahuan dan sains, sekaligus sebagai dinamisasi perguruan tinggi. Akan tetapi perlu dipehatikan, bahwa pengembangan kurikulum itu harus tetap berpijak pada prinsip-prinsip pengembangan kurikulum seperti yang dirumuskan oleh Oemar Hamalik dalam Zainuddin yang membagi delapan macam, yaitu prinsip berorientasi pada tujuan, prinsip berorientasi relevansi (kesesuaian), prinsip efisiensi dan efektivitas, prinsip fleksibilitas, prinsip kontinutas (berkesinambungan), prinsip keseimbangan, prinsip keterpaduan, dan prinsip mutu. ${ }^{14}$

Tujuan pengembangan kurikulum Al-Islam dan Kemuhammadiyahan pada STKIP Muhammadiyah Palopo harus berpijak pada tujuan pendidikan tinggi seperti yang tertuang dalam Peraturan Menteri Riset, Teknologi, dan Pendidikan Tinggi Republik Indonesia Nomor 44 Tahun 2015 tentang Standar Nasional Pendidikan Tinggi Pasal 3 (1) Standar Nasional Pendidikan Tinggi bertujuan untuk: a. menjamin tercapainya tujuan pendidikan tinggi yang berperan strategis dalam mencerdaskan kehidupan bangsa, memajukan ilmu pengetahuan dan teknologi dengan menerapkan nilai humaniora serta

14Zainuddin, Reformasi Pendidikan: Kritik Kurikulum dan Manajemen Berbasis Sekolah, (Cet. I; Yogyakarta: 2008), h. 241. 


\section{0 | Syamsu $S$.}

pembudayaan dan pemberdayaan bangsa Indonesia yang berkelanjutan; $b$. menjamin agar pembelajaran pada program studi, penelitian, dan pengabdian kepada masyarakat yang diselenggarakan oleh perguruan tinggi di seluruh wilayah hukum Negara Kesatuan Republik Indonesia mencapai mutu sesuai dengan kriteria yang ditetapkan dalam Standar Nasional Pendidikan Tinggi; dan c. mendorong agar perguruan tinggi di seluruh wilayah hukum Negara Kesatuan Republik Indonesia mencapai mutu pembelajaran, penelitian, dan pengabdian kepada masyarakat melampaui kriteria yang ditetapkan dalam Standar Nasional Pendidikan Tinggi secara berkelanjutan.

Pelaksanaan manajemen kurikulum Al-Islam dan Kemuhammadiyahan di STKIP Muhammadiyah Palopo berjalan dengan baik dimana pengelolaan kurikulum Al-Islam dan Kemuhammadiyahan (AIK) oleh Tim AIK masingmasing PTM dengan melaksanakan fungsi perencanaan dan pengembangan kurikulum secara reguler setiap awal tahun ajaran baru; pengelolaan materi, metode, media, serta distribusi dosen terstruktur dengan baik; pengimplementasian proses perkuliahan sesuai kurikulum Al-Islam dan Kemuhammadiyahan (AIK); dan evaluasi keseluruhan proses pendidikan AlIslam dan Kemuhammadiyahan (AIK) dilakukan baik dalam bentuk ujian semester, ujian komprehensif, maupun dalam bentuk seminar proposal, seminar hasil dan ujian skripsi.

Pelaksanaan manajemen kurikulum Al-Islam dan Kemuhammadiyahan (AIK) tersebut menjadikan STKIP Muhammadiyah Palopo tetap eksis dan mendapat apresiasi dan partisipasi nyata dari para kader persyarikatan Muhammadiyah yang cukup banyak dan stakeholder lainnya. Untuk peningkatan kualitas proses dan hasil kurikulum Al-Islam dan Kemuhammadiyahan (AIK), maka hal yang penting untuk dilakukan adalah penerapan model pembelajaran yang berpusat pada mahasiswa dengan metode yang bervariatif sehingga mahasiswa dapat menerapkan nilai-nilai AIK dalam kehidupan sehari-hari secara nyata.

Berdasarkan temuan sebagaimana diuraikan di atas tentang pelaksanaan evaluasi kurikulum AIK pada STKIP Muhammadiyah Palopo dilakukan secara parsial dan holistik. Secara parsial kurikulum AIK dievaluasi pada tahap akhir proses perkuliahan dalam bentuk ujian tengah semester, praktikum, dan ujian akhir semester. Sedangkan evaluasi secara holistik dalam bentuk ujian komprehensif yang diujikan pada akhir penyelesaian studi. Oleh karena itu, evaluasi kurikulum yang ditempuh di STKIP Muhammadiyah Palopo didukung oleh pendapat Murray Print, bahwa ... curriculm evaluation involves an examination of the goals, rationale and structure of a teacher' 
curriculm, a study of the context in wich the interaction with students accur. ${ }^{15}$ Evaluasi kurikulum dilakukan untuk mengevaluasi tujuan, struktur, dan interaksi antara dosen dengan mahasiswa. Dengan demikian, dari proses evaluasi tersebut akan diketahui sejauhmana keberhasilan pencapaian kurikulum Al-Islam Kemuhammadiyahan (AIK).

Pelaksanaan manajemen kurikulum Al-Islam dan Kemuhammadiyahan (AIK) pada STKIP Palopo dipandang sebagai perwujudan fungsi-fungsi manajemen, didukung oleh pendapat Wahjosumidjo, bahwa manajemen merupakan proses merencanakan, mengorganisasikan, memimpin, dan mengendalikan usaha anggota oganisasi serta pendayagunaan sumber daya organisasi dalam rangka mencapai tujuan yang telah ditetapkan. ${ }^{16}$ Dalam konteks STKIP Muhammadiyah Palopo kegiatan manajemen secara umum dilakukan pada empat aspek yaitu aspek perencanaan, aspek pengorganisasian, aspek pelaksanaan, dan aspek evaluasi.

Manajemen kurikulum Al-Islam Kemuhammadiyahan (AIK) pada STKIP Palopo harus komitmen mengedepankan pendidikan Islam yang memiliki wawasan membangun sikap dan perilaku beragama loyal, menyiapkan calon calon lulusan yang mampu mengintegrasikan kepribadian yang intelektualprofesional-religius, diwujudkan dalam kehidupan bemasyarakat, berbangsa, dan bernegara serta mampu membentuk lulusan yang profesional pada bidangnya, memiliki karakter, bermoral, dan berakhlak yang sesuai tuntunan Islam yang menjunjung tinggi nilai kemanusiaan.

\section{DAFTAR PUSTAKA}

Arifin, Syamsul. Rekonstruksi Al-Islam Kemuhammadiyahan (AIK) Perguruan Tinggi Muhammadiyah Sebagai Praksis Pendidikan Nilai. EDUKASI: Jurnal Pendidikan Agama dan Keagamaan, Vol. 13, Nomor 2, 2015.

Bharvard, Amru J. Curriculum Evaluation. International Research Journal, Vol. 1 Issue 12, 2010.

Chaudhary, Gautam Kumar. Factors Affecting Curriculum Implementation for Students. International Journal of Applied Research vol. 12, no. 1, 2015

Davis, E. 1980. Teachers as Curriculum Evaluators. Sydney: George Allen \& Unwin.

\footnotetext{
15Murray Print, Curriculum Development and Design, (Australia: National Library of Australia, 1993), h. 188.

16Wahjosumidjo, Kepemimpinan Kepala Sekolah: Tinjauan Teoritik dan Permasalahannya, (Jakarta: RajaGrafindo Persada, 2008), h. 94.
} 
72 | Syamsu $S$.

Hashim, Che Noraini, dan Hasan Langgulung. Islamic Religous Curriculum in Muslim Countries: The Experiences of Indonesia and Malaysia. Bulletin of Education and Research, Vol. 30, No. 1, 2008.

Hussain. Afzan et.al. Evaluation of Curriculum Development. International Journal of Humanities and Social Science Vol. 1, No. 14 October, 2010.

Indrajit, Eko dan R. Djokopranoto. Manajemen Perguruan Tinggi Modern. Yogyakarta: ANDI, 2006.

Rektor Universitas Muhammadiyah Malang. Makalah disampaikan pada Lokakarya Integrasi dan Implementasi Perkuliahan AIK di PTM pada tanggal 18 Juni 2017. http://www.umm.ac.id/id/berita/aik-ciri-khasperguruan-tinggi-muhammadiyah.html

Mulengeki, Felix, et.al. Curriculum Development and Evaluation. Tanzania, University of Tanzania, 2013.

Pedoman Pandidikan AIK, Pendidikan Al-Islam dan Kemuhammadiyahan Perguruan Tinggi Muhammadiyah. Yogyakarta: Majelis Pendidikan Tinggi PP Muhammadiyah, 2013.

Print, Murray. Curriculum Development and Design. Australia: National Library of Australia, 1993.

Republik Indonesia, Peraturan Menteri Riset, Teknologi, dan Pendidikan Tinggi nomor 44 tahun 2015 tentang Standar Nasional Pendidikan.

Roqib, Moh. Ilmu Pendidikan Islam. Yogyakarta: LkiS, 2009.

Sulistyorini. Manajemen Pendidikan Islam. Yogyakarta: Teras, 2009.

Tim Penyusun. Panduan Penyusunan Kurikulum Pendidikan Tinggi. Jakarta: Kemenristek Dikti, 2016.

Wahjosumidjo. Kepemimpinan Kepala Sekolah: Tinjauan Teoritik dan Permasalahannya, (Jakarta: RajaGrafindo Persada, 2008.

Zainuddin. Reformasi Pendidikan: Kritik Kurikulum dan Manajemen Berbasis Sekolah, (Cet. I; Yogyakarta: 2008. 